\title{
Correspondence
}

\section{Cololejeunea nanhutashanensis (Lejeuneaceae), a new species from Taiwan}

\author{
JIA-DONG YANG ${ }^{1,2} \&$ SHAN-HSIUNG LIN ${ }^{2}$ \\ ${ }^{1}$ Division of Botany, Endemic Species Research Institute, Nantou 552, Taiwan \\ ${ }^{2}$ Department of Life Science, Tunghai University, Taichung 407, Taiwan \\ E-mail:slin@thu.edu.tw
}

\begin{abstract}
Cololejeunea nanhutashanensis is described as a new species from Taiwan. The new taxon is included in subgenus Cololejeunea (Spruce) Schiffner, and characterized mainly by its ovate to broadly ovate leaves with obtuse apex; large leaf lobule, 2/3-3/4 of lobe length; lobule with 2 teeth, separated by 2-4 cells from each other; stylus 5-16 cells long, 1-3 seriate; leaf cells thin-walled with large trigones and hemispherical dorsal protrusions; androecia terminal on short lateral branches with male bracts in 3-5 pairs; female bracts large, bract lobule almost as long as bract lobe; perianth obovate to oblong, 5keeled, with dorsal protrusions on upper 1/3 surface. Its main characters are illustrated, and its distinction from other closely related consubgeneric species is discussed.
\end{abstract}

Key words: Cololejeunea, liverworts, taxonomy, Taiwan

\section{Introduction}

Cololejeunea (Spruce 1884: 291) Schiffner (1893: 121) is a large pantropical genus of the liverwort family Lejeuneaceae. In Taiwan 48 species of this genus have been recorded from lowlands to mountain forests at $2500 \mathrm{~m}$ in elevation, mostly on living leaves as epiphylls but some on bark, rock, or decaying wood (Yang 2009; Wang et al. 2011; Ellis et al. 2013).

Examining the Taiwanese specimens of Cololejeunea, we found an interesting taxon from Mt. Nanhutashan area, one of the highest mountains in Taiwan. We compared the specimen with those of Cololejeunea material in Taiwan, and to relevant literature (Pearson 1890; Evans 1902, 1938; Mizutani 1961; Schuster 1980; Paton 1999; Zhu \& So 2001; Yang 2009). We found it not matching the concept of any known species of the genus, and consequently described as a new species.

\section{Material and methods}

The holotype and isotype of the new species are deposited in TUNG and TAIE separately. The samples were studied with the typical anatomically and morphologically. Microscopic examinations and measurements were taken with a Zeiss Imager A2 light microscope and a Jenoptik ProgRes C14 Plus camera mounted on this microscope. Line drawings were prepared using the microphotographs obtained.

\section{Description}

Cololejeunea nanhutashanensis J.D.Yang \& S.H.Lin, sp. nov. (Fig. 1)

Diagnosis: Cololejeunea nanhutashanensis differs from the otherwise similar Cololejeunea biddlecomiae (Aust. in Pearson 1890: 5) Evans (1902: 168) in its leaves with obtuse to rounded apex; large leaf lobule to 2/3-3/4 of lobe length; stylus 5-16 cells long, 1-3 seriate; leaf cells thin-walled with large trigones and hemispherical dorsal protrusions; androecia terminal on short lateral branches with male bracts in 3-5 pairs; female bracts large, bract lobule almost as long as bract lobe; perianth obovate to oblong, 5-keeled, with dorsal protrusions on its upper $1 / 3$ surface. 
TABLE 1. A comparison of characters among Cololejeunea nanhutashanensis, C. biddlecomiae, C. calcarea, and C.

ornate.

\begin{tabular}{|c|c|c|c|c|}
\hline Characters & C. nanhutashanensis & C. biddlecomiae & C. calcarea & C. ornata \\
\hline Plant length & Up to $5 \mathrm{~mm}$ & $3-9 \mathrm{~mm}$ & Up to $5 \mathrm{~mm}$ & Up to $5 \mathrm{~mm}$ \\
\hline Plant width & $0.40-0.65 \mathrm{~mm}$ & $0.50-0.70 \mathrm{~mm}$ & $0.25-0.70(-0.90) \mathrm{mm}$ & $0.25-0.40 \mathrm{~mm}$ \\
\hline Stem width & $33-82 \mu \mathrm{m}$ & $(40-) 50-65 \mu \mathrm{m}$ & $46-70 \mu \mathrm{m}$ & $36-45 \mu \mathrm{m}$ \\
\hline Shape of leaves & Ovate to broadly ovate & Ovate to ovate-lanceolate & Ovate-lanceolate & Ovate \\
\hline Shape of leaf apex & Obtuse & Acute to obtuse & Acute to acuminate & Acute \\
\hline Leaf length & $0.22-0.39 \mathrm{~mm}$ & $0.32-0.40 \mathrm{~mm}$ & $0.30-0.45 \mathrm{~mm}$ & $0.18-0.25 \mathrm{~mm}$ \\
\hline Leaf width & $0.21-0.28 \mathrm{~mm}$ & $0.20-0.25 \mathrm{~mm}$ & $0.15-0.30 \mathrm{~mm}$ & $0.10-0.18 \mathrm{~mm}$ \\
\hline Cell walls & $\begin{array}{l}\text { With large trigones, } \\
\text { dorsal protrusions } \\
\text { hemispherical }\end{array}$ & $\begin{array}{l}\text { With minute trigones, } \\
\text { dorsal protrusions } \\
\text { conical }\end{array}$ & $\begin{array}{l}\text { With small trigones, } \\
\text { dorsal protrusions } \\
\text { conically acute }\end{array}$ & $\begin{array}{l}\text { With small trigones, } \\
\text { dorsal protrusions } \\
\text { spinose }\end{array}$ \\
\hline Leaf lobule & $\begin{array}{l}2 / 3-3 / 4 \text { the leaf length, } \\
\text { surface smooth }\end{array}$ & $\begin{array}{l}1 / 3-1 / 2 \text { the leaf length, } \\
\text { surface smooth }\end{array}$ & $\begin{array}{l}1 / 2-2 / 3 \text { the leaf length, } \\
\text { surface smooth }\end{array}$ & $\begin{array}{l}\text { Up to } 2 / 3 \text { the leaf length, } \\
\text { reduced frequently, surface } \\
\text { densely spinose }\end{array}$ \\
\hline Lobule teeth & $\begin{array}{l}\text { With } 2 \text { teeth, distant, } \\
\text { separated by } 2-4 \text { cells }\end{array}$ & $\begin{array}{l}\text { With } 2 \text { teeth, distant, } \\
\text { separated by } 1-2 \text { cells }\end{array}$ & $\begin{array}{l}\text { With } 2 \text { teeth, distant or } \\
\text { crossing each other, } \\
\text { separated by } 1 \text { cell }\end{array}$ & $\begin{array}{l}\text { With } 2 \text { teeth, distant, } \\
\text { separated by } 1-3 \text { cells }\end{array}$ \\
\hline Stylus & $\begin{array}{l}\text { Linear, } 5-16 \text { cells long, } \\
1-3 \text { seriate }\end{array}$ & $\begin{array}{l}\text { Linear, } 5-8(-12) \text { cells } \\
\text { long, uniseriate, rarely } \\
2-3 \text { cells wide at base }\end{array}$ & $\begin{array}{l}\text { Linear, 2-6(-7) cells } \\
\text { long, uniseriate }\end{array}$ & $\begin{array}{l}\text { Linear, } 2-9 \text { cells long, } \\
\text { 1-3 seriate, denticulate } \\
\text { due to the projecting cells }\end{array}$ \\
\hline Number of Male bracts & $3-5$ pairs & 2-6 pairs & 1-4 pairs & 2-4 pairs \\
\hline Length of female bracts & $0.40-0.70 \mathrm{~mm}$ & ca. $0.35 \mathrm{~mm}$ & ca. $0.35 \mathrm{~mm}$ & $0.22-0.26 \mathrm{~mm}$ \\
\hline Length of female bract & Almost as long as bract & ca. $1 / 2$ the bract lobes & ca. $2 / 3$ the bract lobes & ca. $4 / 5$ the bract lobes \\
\hline lobules & lobes & length & length & length \\
\hline Perianth position & Emergent up to $1 / 5$ & Emergent up to $4 / 5$ & Emergent up to $4 / 5$ & Emergent up to $1 / 3$ \\
\hline Habitat & On trees & On trees or rocks & On limestone, calcicolous & On limestone, calcicolous \\
\hline
\end{tabular}

\section{Acknowledgments}

Thanks are due to James R. Shevock and Chu-Fa Tsai for reviewing the manuscript and making useful suggestions and Tamás Pócs and Rui-Liang Zhu for providing constructive comments. We are grateful to Kui-Chu Chen for assisting in plate preparation. This study was financially supported in part by the National Science Council (NSC 101-2621-B329-001) and the Council of Agriculture, Taiwan.

\section{References}

Ellis, L.T., Bednarek-Ochyra, H., Ochyra, R., Benjumea, M.J., Saïs, L.V., Caparrós, R., Lara, F., Mazimpaka, V., Dulin, M.V., Garilleti, R., Gremmen, N., Grundling, P.-L., Heras, P., Infante, M., Huttunen, S., Ignatov, M.S., Korvenpää, T., Lebouvier, M., Lewis Smith, R.I., Lin, S.-H., Yang, J.-D., Linström, A., Plášek, V., Rosselló, J.A., Sawicki, J., van Rooy, J., Smith, V.R. (2013) New national and regional bryophyte records, 35. Journal of Bryology 35: 129-39. http://dx.doi.org/10.1179/1743282013y.0000000049 
Evans, A.W. (1902) The Lejeuneae of the United States and Canada. Memoirs of the Torrey Botanical Club 8: 113-183.

Evans, A.W. (1911) Hepaticae of Puerto Rico. X. Cololejeunea, Leptocolea, and Aphanolejeunea. Bulletin of the Torrey Botanical Club 38: 251-286.

http://dx.doi.org/10.2307/2479100

Evans, A.W. (1938) Notes on the Genus Cololejeunea. The Bryologist 41: 71-82.

Libert, M.A. (1829) Sur un genre nouveau d'hépatiques, Leveunia. Annales Générales des Sciences Physiques 16: 372-374. http://dx.doi.org/10.2307/3239339

Mizutani, M. (1961) A revision of Japanese Lejeuneaceae. Journal of the Hattori Botanical Laboratory 24: 115-302.

Pearson, W.H. (1890) List of Canadian Hepaticae. W. Foster Brown, Montreal. http://dx.doi.org/10.5962/bhl.title.60082

Paton, J.A. (1999) The liverwort flora of the British Isles. Harley Books, Colchester, 626 pp.

Schiffner, V. (1893) Hepaticae (Lebermoose). In: Engler, A. \& Prantl, K. (Eds.) Die Natürlichen Pflanzenfamilien, Teil. I, Abt. 3. Engelmann, Leipzig, pp. 97-141.

Schuster, R.M. (1963) An annotated synopsis of the genera and subgenera of Lejeuneaceae. Nova Hedwigia, Beihefte 9: 1-203.

Schuster, R.M. (1980) The Hepaticae and Anthocerotae of North America. Vol. IV. Columbia University Press, New York, 1334 pp.

Spruce, R. (1884) Hepaticae Amazonicae et Andinae. I. Transactions and Proceedings of the Botanical Society of Edinburgh 15: 1-308. Stephani, F. (1890) Die Gattung Lejeunea im Herbarium Lindenberg. Hedwigia 29: 68-99.

Wang, J., Lai, M.-J. \& Zhu, R.-L. (2011) Liverworts and hornworts of Taiwan: an updated checklist and floristic accounts. Annales Botanici Fennici 48: 369-395.

http://dx.doi.org/10.5735/085.048.0501

Yang, J.-D. (2009) Liverworts and Hornworts of Taiwan I. Lejeuneaceae. Endemic Species Research Institute, Nantou, 144 pp.

Zhu, R.-L. \& So, M.L. (2001) Epiphyllous liverworts of China. Nova Hedwigia, Beihefte 121: 1-418. 